\title{
Response of a subalpine grassland to simulated grazing: aboveground productivity along soil phosphorus gradients
}

\author{
C. Thiel-Egenter ${ }^{1}$, A. C. Risch ${ }^{1,5}$, M. F. Jurgensen ${ }^{2}$, D. S. Page-Dumroese ${ }^{3}$, \\ B. O. Krüsi ${ }^{4}$ and M. Schütz ${ }^{1}$
}

\author{
${ }_{2}^{1}$ Swiss Federal Institute for Forest, Snow and Landscape Research, 8903 Birmensdorf, Switzerland \\ ${ }^{2}$ Michigan Technological University, School of Forest Resources and Environmental Science, Houghton \\ 49931 MI, USA \\ ${ }^{3}$ USDA Forest Service, Rocky Mountain Research Station, Moscow 83843 ID, USA \\ ${ }^{4}$ University of Applied Sciences Waedenswil, 8820 Waedenswil, Switzerland \\ ${ }^{5}$ Corresponding author: E-mail: anita.risch@wsl.ch
}

Keywords: Cervus elaphus, Grazing history, Grazing pattern, High elevation, Primary production, Swiss National Park.

\begin{abstract}
Interactions between grassland ecosystems and vertebrate herbivores are critical for a better understanding of ecosystem processes, but diverge widely in different ecosystems. In this study, we examined plant responses to simulated red deer (Cervus elaphus L.) grazing using clip-plot experiments in a subalpine grassland ecosystem of the Central European Alps. We measured aboveground net primary production (ANPP) and phosphorus (P) concentration of leaf tissue from plants of two vegetation types with different grazing history. The experimental plots were placed on a soil-P gradient and subject to two different clipping treatments, which simulated moderate and heavy grazing, respectively. We found distinct differences in the response of both ANPP and P concentration in leaf tissues in the two vegetation types. Compared to moderate, heavy grazing simulation did not affect ANPP in the vegetation type adapted to grazing, but decreased ANPP in the non-grazing adapted vegetation type. High soil-P levels also had different effects on the response of the vegetation to clipping in the two vegetation types with different grazing history. ANPP correlated positively with soil-P in non-grazing adapted tall-grass vegetation, while in grazing adapted short-grass vegetation a positive relationship between soil-P and the P concentration in leaf tissues was found. Our experiments provide data for a better understanding of ecosystem processes in high-elevation grasslands of the Alps with possible implications for both nature conservation purposes in protected areas and the management of agriculturally used grasslands.
\end{abstract}

Abbreviations: ANPP - aboveground net primary production; SNP - Swiss National Park; Leaf-P - phosphorus concentration of leaf tissue; soil-P - phosphorus concentration in the top $10 \mathrm{~cm}$ of the mineral soil.

Nomenclature: Aeschimann and Heitz (1996) for higher plants.

\section{Introduction}

Grassland ecosystems and herbivores can interact in many ways. Grazers have been reported to increase or decrease above- and belowground primary production, change species composition, species richness and plant canopy architecture (Collins et al. 1998, Gough and Grace 1998, Knapp et al. 1999, Frank et al. 2002, Virtanen et al. 2002), and influence carbon and nutrient cycling in soils and vegetation (Detling 1988, McNaughton et al. 1997, Frank and Evans 1997, Knapp et al. 1999, Risch and Frank 2006, Schütz et al. 2006).
The response of grassland productivity to grazing can, however, be highly variable between ecosystems. In boreal and arctic ecosystems, the response of the vegetation to grazing has been reported to be negative (Moss et al. 1981, Post and Klein 1996) and neutral (Beaulieu et al. 1996, Post and Klein 1996, Fox et al. 1998, Raillard and Svoboda 1999). In contrast, research conducted in tropical African and Indian savannas and temperate NorthAmerican prairies, showed that grazing by large herbivores enhanced aboveground net primary production (ANPP; e.g., McNaughton 1976, Pandey and Singh 1992, Frank and McNaughton 1993). These examples suggest 
that it is not possible to predict the potential effect of grazers on grassland processes in ecosystems where these interactions have not yet been studied.

Consequently, the goal of this study was to acquire information on how grazing affects ANPP in subalpine grasslands in the Central European Alps, ecosystems that, to our knowledge, have not yet been included when studying the effect of grazers on grassland productivity. More specifically, our objectives were to investigate how simulated heavy and moderate grazing (clipping) affect ANPP and vegetation nutrient concentrations in such grassland ecosystems. We chose to investigate this along a soil-P gradient in two different vegetation types - short-grass and tall-grass - with different grazing histories. We focused on soil-P, since i) $\mathrm{P}$ is the limiting nutrient in subalpine and alpine grassland ecosystems (Dietl 1994); and ii) soil-P is immobile, and therefore leaching losses are low (Hilal et al. 1973). The short-grass type with predominance of red fescue (Festuca rubra L.) has been heavily grazed by red deer (Cervus elaphus L.) for an approximately 80 -year period, while the tall-grass type with predominant Carex sempervirens Vill., is rarely grazed (e.g., Haller 2002, Schütz et al. 2003, 2006). Red fescue grasslands are preferred grazing sites of female red deer and are well adapted to grazing (Charles et al. 1977, CluttonBrock et al. 1982, 1987, Osborne 1984, Gordon 1989, Suter et al. 2004), contrasting grasslands dominated by Cyperaceae, which generally seem to be avoided by these animals (Petrak 1982).

Recently, Bardgett and Wardle (2003) showed in a review that, in general, grazing related stimulation of ANPP occured when i) intensity of grazing was moderate (McNaughton 1979, Dyer et al. 1986, Holland et al. 1992), ii) grazing was coupled with high soil fertility (e.g., Hik and Jefferies 1990, Loreau 1995) or iii) extended periods passed between grazing events (Georgiadis et al. 1989, Hamilton et al., 1998). Based on these general processes of grazer-grassland interactions, we formulated the following hypotheses, which we tested in our experiment:

i) ANPP is higher on grassland adapted to grazing compared to grassland not adapted.

ii) ANPP is positively correlated with soil-P in both vegetation types and under both grazing treatments.

iii) Simulated moderate grazing leads to increased ANPP in the grazing-adapted short-grass vegetation type when associated with high soil-P levels. iv) The $\mathrm{P}$ concentration of leaf-tissue (leaf-P) is positively correlated with soil-P and is enhanced under simulated heavy grazing.

\section{Methods}

Study site

The study was conducted in a subalpine grassland ecosystem of the Swiss National Park. The Park was founded in 1914, and is located in the south-eastern part of Switzerland in the Central European Alps (46 $40^{\circ} \mathrm{N}$, $\left.10^{\circ} 15^{\prime} \mathrm{E}\right)$. The study site, Alp Stabelchod (10.7 ha), is located at $1950 \mathrm{~m}$ and has a uniform slope of six degrees in southerly direction. The underlying parent material consists of calcareous sediments dominated by dolomites (Trümpy et al. 1997). Average annual temperature and precipitation are $0.2^{\circ} \mathrm{C} \pm 0.76$ and $925 \mathrm{~mm} \pm 162$, respectively (means \pm standard deviation; recorded at the Parks weather station: Buffalora $1977 \mathrm{~m}$ ). The growing season starts in early June and ends in late September.

Alp Stabelchod has been created many centuries ago after clear-cutting - first records date back to the year 1421 - and was thereafter used as summer pasture for domestic livestock (cattle/sheep) until the Parks foundation in 1914 (Schorta 1988, Parolini 1995). This former agricultural land use resulted in the development of a distinct soil nutrient pattern: today, the most nutrient-rich areas are found around former huts and stables, the most nutrient-poor areas along the forest edge (Schütz et al. 2003, 2006). After the Parks foundation, grazing pressure was negligible for several years (Braun-Blanquet et al. 1931), since wild ungulates became virtually extinct in this particular area in the early $19^{\text {th }}$ century. During the late 1920's, red deer (Cervus elaphus L.) gradually re-invaded the Park and the population subsequently increased exponentially until the mid 1970's. Today, roughly 2000 animals inhabit the Park during the summer months (Haller 2002). The winter range of this population is in the surrounding lower elevation valleys outside the Park. In spring, red deer gradually follow snowmelt from the lowlands to higher altitudes, and start grazing the Parks subalpine grasslands, such as Alp Stabelchod, in early June (Blankenhorn et al. 1979). Thereafter, most animals migrate to alpine grasslands located above timberline, while hinds with calves remain at lower elevations and regularly visit the subalpine grasslands during the entire growing season. Red deer created distinct patterns on Alp Stabelchod with permanently grazed short-grass patches (plant height approximately $2 \mathrm{~cm}$ ) and rarely grazed tall-grass patches (plant height exceeding $20 \mathrm{~cm}$; Schütz et al. 2003, 2006).

\section{Experimental design}

We stratified Alp Stabelchod into grid cells of $20 \mathrm{~m} \times$ $20 \mathrm{~m}$ dominated by short- and tall-grass based on a vegetation survey conducted in summer 1998 (Achermann 
2000). The short-grass vegetation type is characterized by graminoids such as Festuca rubra L., Briza media L., Poa alpina L., and herbs such as Trifolium repens L., Galium pumilum M., Crepis aurea L, whereas the tall-grass community is dominated by Carex sempervirens Vill.

Based on soil-P concentration data of the top $10 \mathrm{~cm}$ of the mineral soil, which was also collected in summer 1998, we selected 22 pairs of short- and tall-grass grid cells on a soil-P gradient from 144 to $275 \mathrm{mg}$ P per kg soil. The difference in soil-P concentration between cell pairs did not exceed $3 \mathrm{mg} \mathrm{P} \mathrm{kg}^{-1}$. Five additional grid cells with soil-P concentrations between 93 and $135 \mathrm{mg} \mathrm{P} \mathrm{kg}^{-1}$ were selected for the tall-grass vegetation only, since no grid cells existed in the short-grass community with concentrations lower than $144 \mathrm{mg} \mathrm{P} \mathrm{kg}^{-1}$ (Schütz et al. 2006).

Immediately after snowmelt in June 2001 we protected two subplots within each grid cell from large herbivores using grazing-proof wire baskets of $28 \times 48 \times 20$ $\mathrm{cm}$ and a mesh-size of $1.5 \mathrm{~cm}$. We simulated moderate grazing pressure (early season grazing by red deer) by clipping vegetation in one of the two baskets immediately after snowmelt (early June 2001) to the height of $2 \mathrm{~cm}$ above soil surface. Heavy grazing pressure was simulated by clipping re-growth to a height of $2 \mathrm{~cm}$ at monthly intervals (mid-July, mid August, mid-September) in the other basket. The clipped biomass was collected in paperbags, oven-dried to constant weight at $60^{\circ} \mathrm{C}$, and weighed. Yearly aboveground net primary production (ANPP) was calculated as the sum of all clippings of a treatment and grid cell. 2001 summer temperature and precipitation were within the 30-year average (based on weather data recorded between 1975 and 2005 at Parks weather station: Buffalora 1977 m).

\section{Phosphorus concentration of leaf tissue}

We analyzed leaf-P concentrations of all the harvests separately by digesting dried plant tissue with nitric acid and analyzing the digest with inductively coupled plasma optical emission spectrometry (Zarcinas et al 1987). We compared average leaf-P concentration from the monthly clipped plots (heavy grazing) with leaf-P concentrations of the plots with moderate grazing in September.

\section{Statistical analysis}

All data were analyzed with the software package SPSS V11.0 (SPSS, Inc, Chicago, IL, USA). A two-way ANCOVA for each vegetation type was performed to compare seasonal production with grazing treatment and soil-P concentration. Grazing treatment was considered as fixed factor and soil-P as covariate. To compare monthly trends in productivity, a repeated measures ANCOVA model was applied. Within-subject factor was month and between-subject factors were vegetation type and soil-P. Differences in leaf-P concentrations related to grazing treatment and soil-P were analyzed using ANCOVA, with grazing treatment as fixed factor and soil-P as covariate.

All data on biomass were transformed using the natural $\log$ to meet criteria of normality and homogeneity. Data on leaf-P concentrations were not transformed, since they already met criteria of normality and homogeneity. The September harvest of the tall-grass sites, which was clipped monthly, did not show homogeneity of variances since the total amount of material harvested was close to zero for most of the samples. Interactions were only incorporated in a model if they showed significance.

\section{Results}

Aboveground net primary production (ANPP) and soil-P

We found distinct differences in the response of ANPP to simulated grazing along the soil-P gradients in the two vegetation types with different grazing histories: Grazing treatment $(\mathrm{p}=0.96)$ and soil-P $(\mathrm{p}=0.14)$ did not affect ANPP in short-grass, which averaged $93 \mathrm{~g}$ dry biomass $\mathrm{m}^{-2}$ year ${ }^{-1}$ in both grazing treatments (Figure 1). In contrast, tall-grass vegetation ANPP was strongly correlated to soil-P (Figure 1), and was significantly higher under simulated moderate compared to heavy grazing $(\mathrm{p}=0.03)$.

The two vegetation types showed significantly different responses in monthly ANPP over the course of the growing season under simulated heavy grazing $(\mathrm{p}=$ 0.003, Table 1, Figure 2). ANPP decreased from July through August to September in both vegetation types ( $p$ $<0.001$, Table 1, Figure 2), however, late season ANPP in the short-grass vegetation (mid-August until mid-September) was still about one third of what was measured in mid-June/mid-July (13 vs. 40 g dry biomass $\mathrm{m}^{-2}$ ), whereas ANPP ceased during the last clipping interval in the tallgrass type (Figure 2). In contrast to the significant interaction between ANPP and soil-P, no significance was detected between time of clipping and soil-P $(\mathrm{p}=0.14$, Table 1$)$.

\section{Leaf-P and soil-P}

We found significantly higher leaf-P concentrations under simulated heavy compared to moderate grazing in both vegetation types (short-grass: $\mathrm{p}<0.001$, tall-grass: $\mathrm{p}$ $<0.001$, Figure 3, Table 2). Average leaf-P concentration was $34 \%$ higher in the simulated heavy compared to the moderate grazing treatment in the short-grass vegetation (1.08 vs. $0.81 \mathrm{~g} \mathrm{P} \mathrm{kg}^{-1}$ dry biomass). Similar differences 
Table 1. Repeated measures ANCOVA for the effects of vegetation type on monthly ANPP along soil-P gradients, and the interaction effects month $\times$ vegetation type and month $\times$ soil-P on monthly ANPP. Vegetation type short-grass $=$ heavily grazed for approximately 80 -years; vegetation type tall-grass $=$ rarely grazed.

\begin{tabular}{|c|c|c|c|c|c|}
\hline Source & Type III SS & $\mathrm{df}$ & MS & F & $\mathrm{p}$ \\
\hline \multicolumn{6}{|l|}{ Between-subject effects } \\
\hline Vegetation type & 1.99 & 1 & 1.99 & 9.499 & 0.003 \\
\hline Soil-P & 2.207 & 1 & 2.207 & 10.533 & 0.002 \\
\hline Error & 9.638 & 46 & 0.21 & & \\
\hline \multicolumn{6}{|l|}{ Within-subject effects } \\
\hline Month & 7.53 & 2 & 3.765 & 47.562 & $<0.001$ \\
\hline Month $\mathrm{x}$ vegetation type & 95.097 & 2 & 47.548 & 600.661 & $<0.001$ \\
\hline Month $x$ soil-P & 0.313 & 2 & 0.156 & 1.977 & 0.144 \\
\hline Error (month) & 7.283 & 92 & 0.0792 & & \\
\hline
\end{tabular}

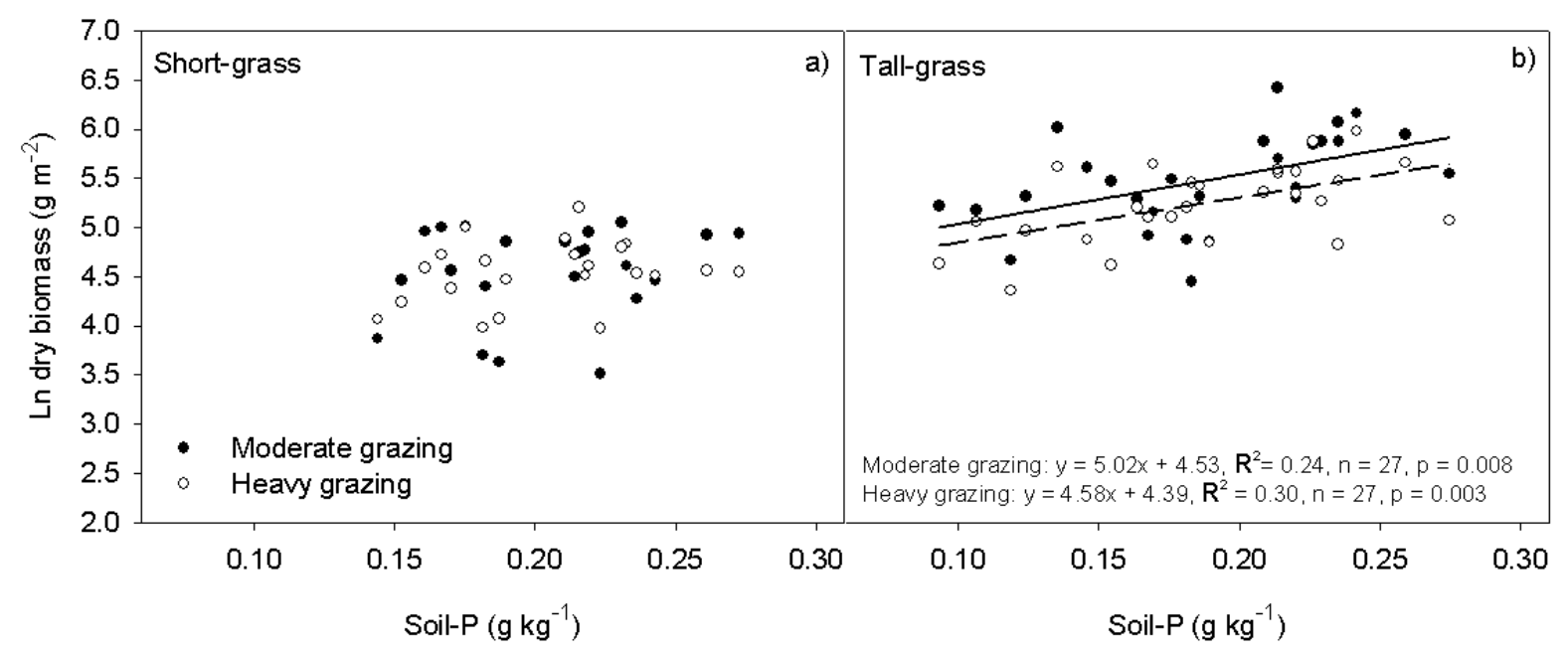

Figure 1. Response of ANPP to moderate and heavy grazing simulation along soil-P gradients in dependence of grazing history: a) short-grass (heavily grazed for approximately 80 -years), b) tall-grass (rarely grazed).

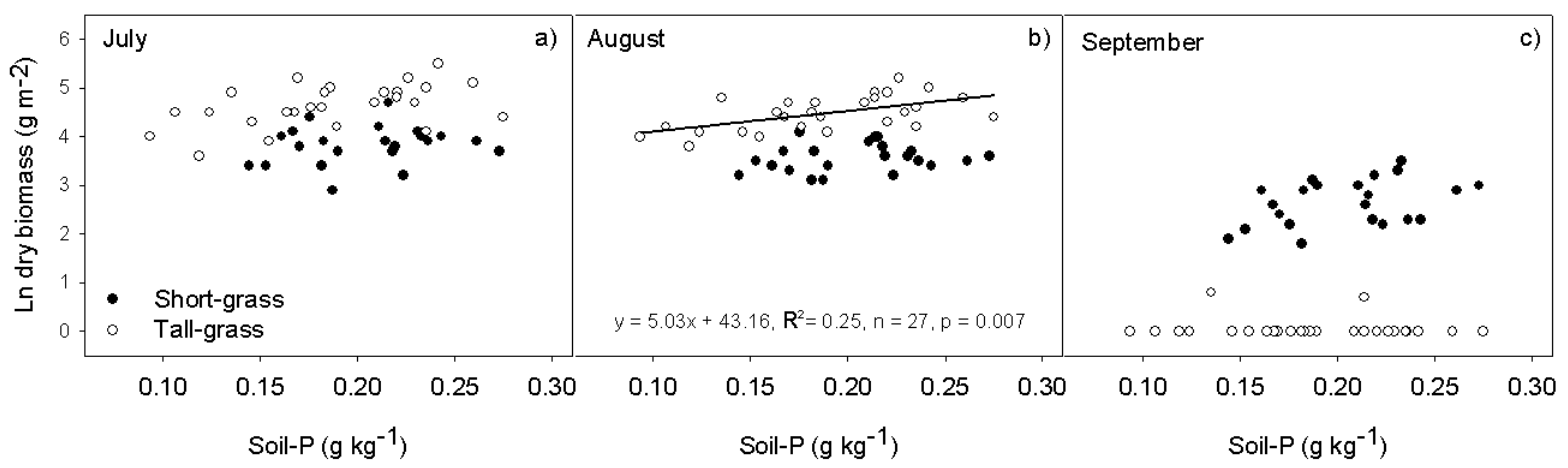

Figure 2. Monthly response of ANPP to heavy grazing simulation along soil-P gradients in dependence of grazing history: a) July, b) August, c) September: vegetation type short-grass = heavily grazed for approximately 80 -years; vegetation type tall-grass = rarely grazed. 
Table 2. ANCOVA for the effects of moderate and heavy grazing simulation along soil-P gradients on leaf-P concentration in two vegetation types with different grazing histories (vegetation type short-grass = heavily grazed for approximately 80 years; vegetation type tall-grass = rarely grazed).

\begin{tabular}{|c|c|c|c|c|c|c|c|c|c|c|c|}
\hline $\begin{array}{l}\text { Short-grass } \\
(n=44)\end{array}$ & Type III SS & $\mathrm{df}$ & MS & $\mathrm{F}$ & $\mathrm{p}$ & $\begin{array}{l}\text { Tall-grass } \\
(\mathbf{n}=54)\end{array}$ & Type III SS & df & MS & $\mathrm{F}$ & $\mathrm{p}$ \\
\hline Soil-P & 0.311 & 1 & 0.311 & 23.934 & $<0.001$ & Soil-P & 0.113 & 1 & 0.113 & 3.410 & 0.077 \\
\hline Block & 0.659 & 20 & 0.033 & & & Block & 0.971 & 25 & 0.039 & & \\
\hline Grazing & 0.811 & 1 & 0.811 & 62.324 & $<0.001$ & Grazing & 1.367 & 1 & 1.367 & 116.508 & $<0.001$ \\
\hline Soil-P x Grazing & 0.120 & 1 & 0.120 & 9.251 & 0.006 & Soil-P x Grazing & 0.004 & 1 & 0.004 & 0.357 & 0.556 \\
\hline Error & 0.260 & 20 & 0.013 & & & Error & 0.293 & 25 & 0.011 & & \\
\hline
\end{tabular}

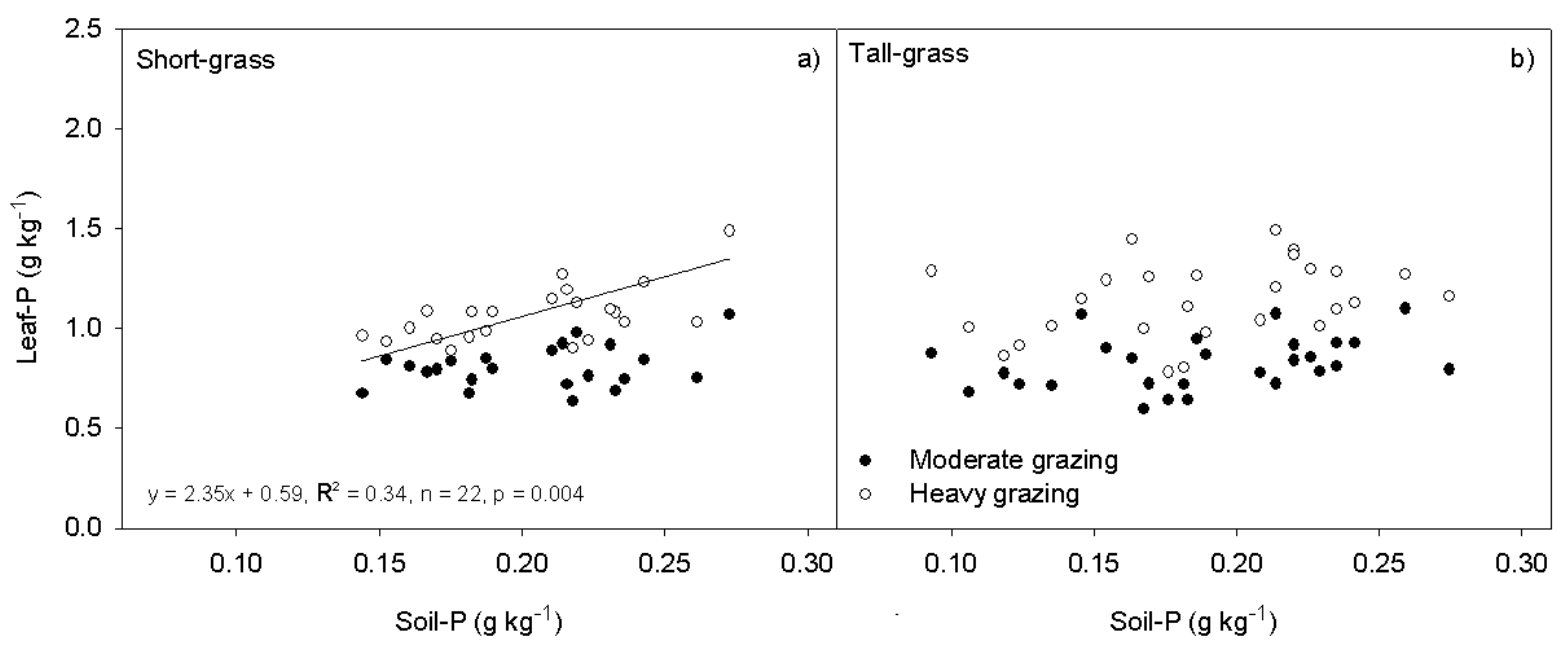

Figure 3. Response of leaf-P concentration to moderate and heavy grazing simulation along soil-P gradients in dependence of grazing history a) short-grass (heavily grazed for approximately 80 -years), b) tall-grass (rarely grazed).

were found for the tall-grass vegetation, where average leaf-P concentration was found to be $39 \%$ higher in plant material harvested from simulated heavy compared to moderate grazing treatment ( 1.14 vs. $0.82 \mathrm{~g} \mathrm{P} \mathrm{kg}^{-1}$ dry biomass, Fig. 3, Tab. 3). Soil-P, however, only had a significant effect on leaf-P concentrations in the short grass vegetation under heavy grazing (Figure 3, Table 2).

\section{Discussion}

\section{Grazing history}

We were interested in how grazing adapted (shortgrass) and non-grazing adapted (tall-grass) vegetation would respond to experimentally simulated grazing along a soil-P gradient. In contrast to our expectations, we found lower ANPP in the grazing adapted short-grass compared to the non-grazing adapted tall-grass vegetation. Our results are similar to findings from American tall-grass prairies, where grazing adapted plots produced less biomass than ungrazed plots (Turner et al. 1993, Knapp et al.
1999), but contrast research from the Serengeti (McNaughton 1985) and Yellowstone National Park (Frank and McNaughton 1993), where higher ANPP was found in grazed compared to ungrazed grassland. Since these latter grasslands are nutrient limited, large mammals are likely to accelerate nutrient cycling through dung and urine input. The production of our grazing adapted short-grass vegetation was, in contrast, not nutrient limited as ANPP was independent of the soil-P concentration and also of dung input by red deer (Schütz et al. 2006). Yet, in this vegetation type there was close to no dung input (Schütz et al. 2006) and ANPP therefore not stimulated.

Another possible reason for not finding a positive response to grazing in our grazing adapted short-grass vegetation could be that the time frame for coexistence between red deer and their forage was not sufficiently long, similarly to what Knapp et al. (1999) showed for the Konza prairie in Kansas, USA. In savanna grasslands of the Serengeti and the prairies of western North America 
(Yellowtone National Park), plants and large herbivores coevolved for millions of years (Stebbins 1981, Holland et al. 1992, McNaughton 1993, Hobbs 1996), which leads to a high sustainability of the grasslands (Frank et al. 1998), and may account for the stimulation of plant productivity.

\section{Grazing intensity and soil-P}

Our results also showed significantly different responses of ANPP to simulated heavy grazing among the two vegetation types: ANPP completely ceased at the end of the season in the tall-grass vegetation, while only a slight drop was detected in the short-grass vegetation. Consequently, we found a neutral response of ANPP to heavy grazing in the short-grass vegetation, while the one in the tall-grass vegetation was negative. These findings contrast our hypotesis, but are similar to what has been reported from arctic and boreal ecosystems (e.g., Post and Klein 1996, Beaulieu et al. 1996, Raillard and Svoboda 1999).

We expected increasing plant growth with increasing soil-P concentration in the short-grass vegetation, however, to our surprise, we only found this effect in the tallgrass vegetation. The reasons for not finding any response of ANPP in the short-grass likely was related to the small amount of biomass produced, which likely is a result of overgrazing. Red deer removed on average $85 \%$ of ANPP and the grassland only produced $93 \mathrm{~g} \mathrm{~m}^{-2}$ year ${ }^{-1}$ aboveground biomass in our study area (Schütz et al. 2006). Fescue dominated pastures generally would produce considerably more ANPP when less intensively grazed as shown by Dietl (1994) for other areas of Switzerland where ANPP was between 150 and $350 \mathrm{~g} \mathrm{~m}^{-2}$ year $^{-1}$.

As expected, we found significantly higher leaf-P concentrations under heavy compared to moderate grazing regardless of vegetation type. The reason for this can be twofold. First, the quality of young leaf-tissue is generally higher than the one of older leaves (McNaughton 1979). Second, as shown in grazing simulation models (Holland and Detling 1990, Seagle et al. 1992), grazing can lead to decreases in carbon allocation to roots, which results in decreased root- and microbial biomass. This in turn, results in increases in the ratio of nutrient mineralization/immobilization and facilitates plant nutrient uptake.

Our results showed distinct differences in the response of grazing adapted and non-adapted high-elevation grasslands to clipping. Since the response of grazing ecosystems can be highly variable across continents and climates, our experiment conducted in the Alps provides important information for a better understanding of grazer-grassland interactions. Further, the knowledge from the results gained might become important for implementing conservation strategies for protected areas as well as the management of agriculturally used grasslands.

Acknowledgments. We thank the authorities of the Swiss National Park for their permission to conduct this unusual and controversially discussed field work. The field assistance provided by V. and D. Egenter, D. Thiel and C. Elmiger and the laboratory work conducted by the USDA Forest Service, Rocky Mt. Research St., Forestry Science Laboratories, Moscow ID and Rocky Mt. Research Laboratory, Logan UT, at the Utah State University is very much appreciated. We are grateful for the statistical advice provided by W. Blanckenhorn and L. Gygax at the University of Zurich.

\section{References}

Aeschimann, D. and C. Heitz. 1996. Synonymie-Index der Schweizer Flora und der angrenzenden Gebiete. CRSF, Genève.

Achermann, G. 2000. The influence of red deer (Cervus elaphus L.) upon a subalpine ecosystem in the Swiss National Park. PhD Thesis, ETH 13479, Zürich, Switzerland.

Bardgett, R. D. and D. A. Wardle. 2003. Herbivore-mediated linkages between aboveground and belowground communities. Ecology 84: 2258-2268.

Beaulieu, J., J. Gauthier and L. Rochefort. 1996. The growth response of graminoid plants to goose grazing in high arctic environment. J. Ecol. 84: 905-1014.

Blankenhorn, H. J., C. Buchli, P. Voser and C. Berger. 1979. Bericht zum Hirschproblem im Engadin und im Münstertal. Eidgenössisches Oberforstinspektorat, Bern.

Braun-Blanquet, J., S. Brunies, E. Campell, E. Frey, H. Jenny, C. Meylan and H. Pallmann. 1931. Vegetationsentwicklung im Schweizerischen Nationalpark. Ergebnisse der Untersuchung von Dauerbeobachtungsflächen. Jahresbericht der Naturforschenden Gesellschaft Graubündens 69: 3-82.

Charles, W. N., D. McCowan and K. East. 1977. Selection of upland swards by red deer (Cervus elaphus L.) on Rhum. J. Appl. Ecol. 14: 55-64.

Clutton-Brock, T. H., G. R. Iason, S. D. Albon and F.E. Guiness. 1982. Effects of lactation on feeding behaviour and habitat use in wild red deer hinds. J. Zool. 198: 227-236.

Clutton-Brock, T. H., G. R. Iason and F. E. Guiness. 1987. Sexual segregation and density-related changes in habitat use in male and female red deer (Cervus elaphus L.). J. Zool. 211: 275-289.

Collins, S. L., A. K. Knapp, J. M. Briggs, J. M. Blair and E. M. Steinauer. 1998. Modulation of diversity by grazing and mowing in native tallgrass prairie. Science 280: 745-747.

Detling, J. K. 1988. Grasslands and savanna: regulation of energy flow and nutrient cycling by herbivores. Ecol. Stud. 67: 131148 .

Dietl, W. 1994. Bewirtschaftung der Alpweiden. In: P. Wäfler (ed.), Alpwirtschaft. LMZ, Zollikofen, pp. 20-33.

Dyer, M. I., D. L. DeAngelis and W. M. Post. 1986: A model of herbivore feedback on plant productivity. Math. Biosci. 79: 171184.

Fox, A. D., J. N. Kristiansen, D. A. Stroud and H. Boyd. 1998. The effects of simulated spring goose grazing on the rate and protein content of Phleum pratense leaves. Oecologia 116: 154-159. 
Frank, D. A. and S. J. McNaughton. 1993. Evidence for the promotion of aboveground grassland production by native large herbivores in Yellowstone National Park. Oecologia 96: 157-161.

Frank, D. A. and R. D. Evans. 1997. Effect of native grazers on grassland N cycling in Yellowstone National Park. Ecology 78: 22382248.

Frank, D. A., S. J. McNaughton and B. F. Tracy. 1998. The ecology of the earth's grazing ecosystem. Bioscience 48: 513-521.

Frank, D. A., M. M. Kuns and R. Guido. 2002. Consumer control of grassland plant production. Ecology 83: 602-606.

Georgiadis, N. J., R. W. Ruess, S. J. McNaughton and D. Western. 1989. Ecological conditions that determine when grazing stimulates grass production. Oecologia 81: 316-322.

Gordon, I. J. 1989. Vegetation community selection by ungulates on the isle of Rhum. II. Vegetation community selection. J. Appl. Ecol. 26: 53-64.

Gough, L. and J. B. Grace. 1998. Herbivore effects on plant species density at varying productivity levels. Ecology 79: 1586-1594.

Haller H. 2002. Der Rothirsch im Schweizerischen Nationalpark und dessen Umgebung. Nationalpark-Forschung in der Schweiz 91: 3-140.

Hamilton, E. W., M. S. Giovanni., S. A. Moses, J. S. Coleman and S. J. McNaughton. 1998. Biomass and mineral element responses of a Serengeti short-grass species to nitrogen supply and defoliation: compensation requires a critical [N]. Oecologia 116: 407-418.

Hik, D. S. and R. L. Jefferies. 1990. Increases in the net aboveground primary production of a salt marsh forage grass: A test of the predictions of the herbivore-optimization model. J. Ecol. 78: 180-195.

Hilal, M. H., F. Anter and A. H. El-Damaty. 1973. A chemical and biological approach towards the definition of calcareous soils. I. Movement and retention of $\mathrm{P}^{12}$ in soils as affected by percentage and particle size of calcium carbonate fraction. Plant Soil 39: 469-478.

Hobbs, N. T. 1996. Modification of ecosystems by ungulates. $J$. Wildl. Manage. 60: 695-713.

Holland, E. A. and J. K. Detling. 1990. Plant response to herbivory and belowground nitrogen cycling. Ecology 71: 1040-1049.

Holland, E. A., W. J. Parton, J. K. Detling and D. L. Coppock. 1992. Physiological responses of plant populations to herbivory and their consequences for ecosystem nutrient flow. Am. Nat. 140: 685-706.

Knapp, A. K., J. M. Blair, J. M. Briggs, S. L. Collins, D. C. Hartnett, L. C. Johnson and E. G. Towne. 1999. The keystone role of bison in North American tallgrass prairie. Bioscience 49: 39-50.

Loreau, M. 1995: Consumers as maximizers of mater and energy flow by grazing. Am. Nat. 145: 22-42.

McNaughton, S. J. 1976. Serengeti migratory wildebeest: Facilitation of energy flow by grazing. Science 191: 92-94.

McNaughton, S. J. 1979. Grazing as an optimization process: Grassungulate relationships in the Serengeti. Am. Nat. 113: 691-703.

McNaughton, S. J. 1985. Ecology of a grazing ecosystem: the Serengeti. Ecol. Monogr. 55: 259-294.

McNaughton, S. J. 1993. Grasses and grazers, science and management. Ecol. Appl. 3: 17-20

McNaughton, S. J., F. F. Banyikwa and M. M. McNaughton. 1997. Promotion of the cycling of diet-enhancing nutrients by African grazers. Science 278: 1798-1800.
Moss, R., D. Welch and P. Rothery. 1981. Effects of grazing by mountain hares and red deer on the production and chemical composition of heather. J. Appl. Ecol. 18: 487-496.

Osborne, B. C. 1984. Habitat use by red deer (Cervus elaphus L.) and hill sheep in the West Highlands. J. Appl. Ecol. 21: 497-506.

Pandey, C. B. and J. S. Singh. 1992. Rainfall and grazing effects on net primary productivity in a tropical savanna, India. Ecology 73: 2007-2021.

Parolini, J. D. 1995. Zur Geschichte der Waldnutzung im Gebiet des heutigen Nationalparks. PhD Thesis, ETH 11187, Zürich, Switzerland.

Petrak, M. 1982. Etho-ökologische Untersuchungen an einer Rothirschpopulation (Cervus elaphus L.) der Eifel unter besonderer Berücksichtigung der stoffwechselbedingten Verhaltens. Wildbiologie und Jagdwissenschafften 10: 1-196.

Post, E. S. and D. R. Klein. 1996. Relationship between graminoid growth form and levels of grazing by caribou (Rangifer tarandus) in Alaska. Oecologia 107: 364-372.

Raillard, M. C. and J. Svoboda. 1999. Exact growth and increased nitrogen compensation by the arctic sedge Carex aquatilits var. Stans <?? after simulated grazing. Arctic, Antarctic, Alpine Research 31: 21-26.

Risch, A. C. and D. A. Frank. 2006. Carbon dioxide fluxes in a spatially and temporally heterogeneous temperate grassland. Oecologia 147: 291-302.

Schorta, A. 1988. Vez l'alp da Grimmels. Istorgia da las alps da Zernez. Octopus, Chur, Switzerland.

Seagle, S. W., S. J. McNaughton and R. W. Ruess. 1992. Simulated effects of grazing on soil nitrogen and mineralization in contrasting Serengeti grasslands. Ecology 73: 1105-1123.

Schütz, M., A. C. Risch, E. Leuzinger, B. O. Krüsi and G. Achermann. 2003. Impact of herbivory by red deer (Cervus elaphus L.) on patterns and processes in subalpine grasslands in the Swiss National Park. Forest Ecol. Manage. 181: 177-187.

Schütz, M., A. C. Risch, G. Achermann, C. Thiel-Egenter, D. S. Page Dumroese, M. F. Jurgensen and P. J. Edwards. 2006. Phosphorus translocation by red deer on a subalpine grassland in the Central European Alps. Ecosystems 9: 624-633.

Stebbins, G. L. 1981. Coevolution of grasses and herbivores. Annales Missouri Botanical Garden 68: 75-86.

Suter, W., U. Suter, B. O. Krüsi and M. Schütz. 2004. Spatial variation of summer diet of red deer Cervus elaphus in the eastern Swiss Alps. Wildlife Biology 10, 43-50.

Trümpy, R., S. M. Schmid, P. Conti and N. Froitzheim. 1997. Erläuterungen zur geologischen Karte 1:50 000 des Schweizerischen Nationalparks. Nationalparkforschung in der Schweiz 87: $1-40$.

Turner, C. L., T. R. Seastedt and M. I. Dyer. 1993. Maximization of aboveground grassland production: The role of defoliation frequency, intensity, and history. Ecol. Appl. 3: 175-186.

Virtanen, R., G. R. Edwards and M. J. Crawley. 2002. Red deer management on the Isle of Rum. J. Appl. Ecol. 39: 572-583.

Zarcinas, B. A., B. Cartwright and L. R. Spouncer. 1987. Nitric acid digestion and multi element analysis of plant material by inductively coupled plasma spectrometry. Communications in Soil Science and Plant Analysis 18: 131-146.

Received 14 December, 2006 Revised May 2, 2007 Accepted May 27, 2007 